\title{
'Cometh the hour, cometh the Dave': how far is the Conservative Party's revival all down to David Cameron?
}

\author{
Tim Bale, University of Sussex
}

The secret of politics, like the secret of comedy, is timing, which may be why the two pursuits often seem to have so much in common. Gordon Brown - after an uncomfortable spell as Mr Bean - is certainly laughing more these days and even hoping for a happy ending. But while his confident handling of the global credit crunch stands an outside chance of saving his government's bacon, the likelihood is that the recession will make it harder rather than easier for Labour to hang on to power in a year or so - by which time the economy may be beginning to recover sufficiently to afford the Tories (assuming they can avoid massive tax increases and/or spending cuts) a second victory on the trot, say in 2014. When accounting for a potential Conservative win in 2009 or 2010, however, we are dealing with more than just another case of 'The economy, stupid'. A Tory victory, after all, began to look possible within days of David Cameron assuming the leadership - long before things turned truly pear-shaped on the financial front. ${ }^{1}$ Given his Party had been 'flatlining' for around a decade, such a rapid turnaround requires some explanation.

Clearly not all the reasons behind that turnaround have to do with Cameron himself. The challenges presented to him by both the external environment and the state of his own party provide a sharp contrast to those faced by his three predecessors as leader of the opposition, let alone by the last Tory premier, John Major. Moreover, it is easy to overdo the pace, nature and scope of change achieved by Cameron in such a short space of time: survey research, for example, suggests that the public is less hostile to but still ambivalent about the Tories; meanwhile, one can argue that they have not so much dumped their ideology overboard as tempered and complemented it. ${ }^{2}$ For all this, however, it is undeniable that the fortunes of the Conservative Party have revived under Cameron's leadership in a way that they patently failed to do under his predecessors, none of whom have had anything like his success in doing the things that Tory oppositions have traditionally (and very successfully) done to put themselves back in contention. ${ }^{3}$ Nor would it be fair to say that he is simply a lucky general, riding the wave of historical inevitability. After all, many find themselves in the right place at the right time, but still fail to do the right things. 'Cometh the hour, cometh the man' - or in this case, as political columnist Matthew Parris put it just after Cameron was chosen as leader, 'the Dave'. ${ }^{4}$

\section{The hour: why Cameron has it easier than his predecessors.}

David Cameron is clearly operating in what - for an opposition party at least - is a more benign external environment than his predecessors. The Labour government faced by William Hague, Iain Duncan Smith and Michael Howard had its fair share of problems. But, until the invasion of Iraq fatally undermined confidence in Tony Blair, it was barely troubled by the main opposition. Not only was it led by one of the most gifted party leaders this country has ever seen, it had inherited and successfully 
maintained an extraordinarily (if only superficially) healthy economy. This had allowed it to realise, albeit imperfectly, Blair's central claim, namely that there need be no trade off between economic efficiency and social justice. Relying not simply on borrowing but on buoyant tax receipts, Gordon Brown was able to deliver unprecedented increases in spending on health and education. Moreover, helped by both the electorate's innate sense that you can't get something for nothing and the Conservative's underinvestment in public services in the 1980s and 1990s, the Blair government was able to persuade voters that even the most marginal of tax cuts would automatically lead to the closure of schools and hospitals. Meanwhile, though rarely able to overturn the Tories' ownership of issues like crime, immigration and defence, New Labour proved itself sufficiently concerned about them to prevent them becoming electorally damaging - a move which also tempted the Conservatives to adopt populist positions that, while they struck a chord with Labour voters, failed to prompt them to defect and managed to alienate some of the Tories' educated, middleclass support.

Cameron, by contrast, started his time as leader of the opposition facing a Prime Minister who was evidently nearing, or was even past, his sell-by date. He was also aided by the widely predicted failure of Blair's successor - once his initial bounce was cancelled out by the incredible run of ill-fortune that followed his bottling of an early election - to connect with the British public. Moreover, that public (or sections of it) was at last beginning to chafe against the more or less stealthy rises in taxation that had been used to pay for improvements in public services that were either banked without much gratitude or regarded with some scepticism given their apparent failure to match the money spent. More recently, of course, Labour's luck on the economy has run out, too. The feelgood factor has long since disappeared, while all the indicators suggest that Brown's implicit claim to have abolished boom and bust was little more than a hollow boast. After occupying Downing Street for more than eleven years, the government may try to claim that its handling of the recession will be more effective and more humane than the Tories' efforts at the beginning of the eighties and nineties. But it can no longer suggest - as it did for so long - that any problems either in the public or the private sector are the fault of the last Conservative government. 'Voters', as eminent American political scientist V.O. Key once put it, 'are not fools.'

David Cameron also leads a party which, irrespective of his own efforts, is both more malleable and more manageable than the one which confronted (sometimes in the literal sense of the word!) his predecessors. ${ }^{5}$ There are many reasons for this. One is simply that the people and the issues that made it so hard for them - even if they didn't exactly help themselves - have moved on. One does not need to buy into the cod-psychology that puts the Party's troubles down to the matricide of Margaret Thatcher in November 1990, to realise that the medical force majeure that has seen her transformed over time from a constantly carping critic into a venerable historical figure has provided its own resolution. Likewise, the parliamentary party Cameron leads is not the same one that witnessed her glory days, or her going, at first hand. Indeed, over half of Tory MPs elected in 2005 won their seats after 1997. ${ }^{6}$ The exit from the Commons, either by death or retirement, of the old and the bold who 
remembered who said what to whom on the night she was knifed has drained some of the poison. The heat, too, has (though not necessarily for ever) gone out of the issue that became their casus belli. The realisation that this country is unlikely to adopt the euro and the obstacles faced by the Lisbon Treaty has put the issue where it has been for most of the electorate if not most of the Conservative Party, namely way down the list of priorities. Equally importantly, the determination of Hague and then Duncan Smith to ensure the triumph of Euroscepticism, combined with the decision by Duncan Smith and then Howard not to make too much of that triumph, calmed things down considerably.

The new intakes of 2001 and 2005, and to a lesser extent 1997, are not necessarily less right-wing than the men (and handful of women) they replaced, but they regard Euroscepticism as a given rather than a touchstone, and they admire Thatcher without worshipping her. They - and some of the younger members of the still shrinking party in the country - are also more comfortable with the UK as it is rather than how it used to be. Political correctness may still be frowned upon, especially of course when 'gone mad'. But it no longer encompasses the defence of words or deeds that are explicitly or even implicitly discriminatory towards women and ethnic minorities. By the same token, while they would of course deprecate the idea that a party should form its policies on the basis of survey research or focus groups, fewer and fewer believe that the saloon bar of the Dog and Duck, or for that matter the pages of the Daily Mail, are a far better way of finding out what voters really think. That in itself is a marked contrast with the attitudes of many of those that the Party's pollsters and Central Office strategists had to cope with for years after Labour's landslide. Also in marked contrast to the party bequeathed by John Major to his successors is the comparative lack of hard and fast factions. Meanwhile, as the Party has ticked off the years between 1997 and 2009, exhaustion has given way first to frustration and finally to hunger. Many of those most recently elected have seen the men and women they worked for as researchers and volunteers spend the best years of their political lives in opposition and they have no intention of doing the same themselves.

It may be banal, even trite, to say, as many Tories do say, that those were years that their party simply had to get through. But there is nevertheless some truth in the idea. For an institution ideologically convinced that it had a monopoly on wisdom and that its main opponent was essentially a pale imitation guaranteed to let down the electorate, it was always going to take more than one big defeat to see it even start to come to its senses. This was especially the case when the print media that plays such a big part - some would say too big a part - in the counsels of the Party called not for moderation (as did the papers loyal to Labour in the 1980s and early 1990s) but for more of the same. Here, too, there has been some change. It would be an exaggeration to say that the right-wing press is wholly convinced by the Cameron project: the Daily Mail is still edited by Paul Dacre, hardly a mincing metrosexual, while the Telegraph titles still have their doubts. But both recognise that Cameron is the only game in town, now and in the foreseeable future. The speculation that Hague, and in particular Duncan Smith, had to put up within months or even days of winning the leadership is notable by its absence in any of the papers. The Express is 
fully on board, while Rupert Murdoch's News International titles are likely, as always, to follow their readers, which on current form suggests relatively favourable coverage: it is hard to imagine, for example, the Sun these days going with a front page comprising David Cameron's head superimposed on a dead parrot - an indignity William Hague had to suffer after barely a year in post. 


\section{Not such a hard act to follow: why Cameron could hardly have done worse than those who went before him}

Given the interference and intriguing of the press during Tory leadership contests since John Major urged his rivals to put up or shut up in 1995, it is tempting to suggest that those looking for evidence of the media's impact on politics might be better advised to look at those relatively small-scale elections than the large-scale national affairs they normally focus on. But the fact is that, even without the newspapers telling them who to vote for after 1997, Conservatives would have been prevented by their own prejudices (either on Europe or on matters sexual) from electing the leaders who might have accelerated what has become known as modernisation. Instead they chose men who, in their own ways, were manifestly not up to doing what needed to be done, namely to make straight for the centre-ground and stay there come what may, all the while attempting to show that the Party bore at least a passing resemblance to a twenty-first century Britain it actually liked rather than deplored.

For all the affection and esteem in which he is now held by his Party, William Hague was never taken seriously by the electorate after early PR gaffes. ${ }^{7}$ Perhaps due to his inexperience, his judgement was also questionable, particularly, say many Tories, when it came to his choice of advisors. Some - understandably given their boss's lamentable, even laughable, image - were more concerned with protecting his own position rather than promoting the interests of the Party. At very least, they were in danger of conflating the two things. Others were simply wedded - or believed there was no realistic alternative - to avoiding a fight with Labour on the bread and butter issues that really mattered, particularly health and education. Better they insisted, against the advice of their own pollsters, to focus on the kind of tub-thumping and headline-chasing which, they argued, would not only mobilise their own supporters but also woo some of Labour's more narrow-minded and self-interested voters into the Conservative camp. ${ }^{8}$ Stung by the internal reaction to a speech by his deputy which hinted at a move back to the centre ground, and believing that the scepticism which helped the Party win the European Parliament elections in 1999 could pay dividends in a national contest, Hague sank back into his own, essentially Thatcherite, comfort zone. ${ }^{9}$

Iain Duncan Smith, it was cruelly claimed, was William Hague without the brains or, for that matter, the witty repartee. Hopeless in the Commons and on TV and radio, he too was unable, under the pressure of opinion polls that refused to shift, of a rightwing press that continually called not for moderation but for more red-meat, and of his own Thatcherite instincts, to stick to what passed for a political strategy. To say that the 777 days that he served as Conservative Party leader were a complete waste of time would be too harsh. Like Michael Foot, he might, ironically, have done the Party some good by supposedly being so bad. More positively, Duncan Smith did begin to point the way, albeit fitfully, towards a concern for those left behind or untouched by prosperity that would bear fruit or at least some resemblance to what was to come. Ultimately, however, he presided over a party that risked descending 
into anarchy, that (as under Hague) was unable to call on the services of many of its most talented individuals, that eventually lost the confidence of the economic interests which funded it, and whose ideas were still some way away from the preferences of the electorate whose votes it needed to return to power.

In so doing, IDS all but obliged the Party to turn to a politician who was no more likely to help it achieve that last aim - at least in the short-term - than he was himself. Michael Howard may well have saved Conservative MPs from themselves by providing the grip and the gravitas needed to produce the self-discipline they so sorely lacked under Duncan Smith. He may even, very briefly, in what to all intents and purposes was his first big speech as leader (at London's Saatchi Gallery) have provided a ray of hope to those within his own ranks who believed that salvation lay in the centre ground. But, no less of a Thatcherite than his predecessors, and even less enamoured than they were of 'the vision thing' he, like them, quickly returned to what since 1997 had become the Conservatives' comfort zone. He, too, seemed prepared to concede that Labour could not be beaten unless its spending plans for schools and hospitals were matched. But he likewise insisted that this need not rule out tax cuts and ensured that it would anyway be drowned out by promises to crack down on crime, immigration and even gypsies. The result was woeful. True, the Tories picked up extra seats in 2005 whereas in 2001 they had virtually stood still. But they still won less than Labour had done at its own low point in 1983 notwithstanding the fact that Blair had become a liability rather than an asset and confidence in the government as a whole was rapidly draining away.

Yet Howard can justly claim to have done David Cameron, and therefore his party, a favour or two. For one thing, he effectively tested to destruction the claim that if only the Conservatives shouted louder rather than really listened to the electorate they would persuade it to listen. If the options open to political parties eventually come down to a choice between 'preference shaping' (the heroic assumption that you can get voters to see things your way) and 'preference accommodation' (the assumption that you need to adjust to what they think), then the Tories' result in 2005 may have encouraged more of them finally to consider giving the second option a go especially after Howard organised a series of forums for his post-election parliamentary party where they were treated to presentations on how poorly the Party was perceived by the public. For another, Howard, despite putting up with considerable flak (now forgotten) for doing so, managed to delay a leadership contest in which Cameron emerged not only as head-and-shoulders above his rivals in terms of presentational skills but with a mandate - and just as importantly a fully-formed plan - to change his party.

\section{The man (and the strategy): what's so different about David Cameron?}

As Malcolm Gladwell's recent bestseller, Outliers, reminds us, success in almost any field relies powerfully on legacy, opportunity, and cultural milieu. But this does not mean we can completely discount innate ability and individual commitment. ${ }^{10}$ The time lag between the Tories losing the election and electing their new leader in 2005 
meant that, instead of spending much of his leadership, like Hague and Duncan Smith, searching for a strategy, Cameron could start straight away to implement one. Just as importantly, however, it was a strategy to which Cameron (along with those in his inner circle like Steve Hilton, George Osborne, Michael Gove, Kate Fall, Ed Llewellyn and Ed Vaizey) was not only intellectually but also emotionally committed. This could not have been said about his predecessors or the people they preferred to have around them, few of whom (as even Team Cameron's detractors grudgingly admit) could claim to be as bright, or as well-blooded in both the Tory media and the Tory Party, as they so obviously were. This, plus the fact that the so-called 'Notting Hill Set' were personal friends with a common project, rather than simply an entourage thrown together by adversity, suggested - even to those who were opposed to them - that they were much less likely to abandon the strategy under pressure.

The bare bones of that strategy will be familiar to many. Based on the idea that the Conservative 'brand' was badly 'contaminated', Cameron would begin by doing everything in his power to communicate to the electorate that the Party was changing and, every bit as importantly, was moving back into the centre ground, the alternative to which was, he claimed, was 'irrelevance, defeat and failure.'11 Media silence would be maintained on the issues that the Party had been 'banging on' about for far too long - not just Europe, which Duncan Smith and Howard had also played down, but also the other parts of the so-called 'Tebbit trinity', immigration and tax. The vacuum created would be filled by Cameron talking about (and creating striking visual images around) issues not normally associated with the Tories, notably the environment, as well as international development, corrosive consumerism, and worklife balance. Meanwhile, Cameron would challenge Labour's automatic ownership of the NHS and state schooling by stressing his own family's reliance on them - and the government's internal divisions on health and education policy - to persuade voters that the Conservatives cared about the many rather than (as appeared to be the case under his predecessors) the few who could be helped to opt-out. Public sector professionals, many of whom worked in those sectors, would also be wooed by assurances that they were valued and that their professional discretion, eroded by Labour's 'target culture' would be restored by a Conservative government. At the same time, the leadership would change the system for selecting parliamentary candidates in order to make it more likely that the Party would put up more women and ethnic minority candidates. Finally, the leadership would implicitly distance itself from the Thatcher years not by apologising for them but by stressing, in effect, that was then but this is now.

The aim of all this was, firstly, to convince the electorate (and particularly the middle classes that historically have been the Conservatives' real 'core vote') that the Tories were a pragmatic and moderate alternative to Labour, and secondly to obtain them 'permission to be heard.' Once voters could be persuaded not to automatically discount Conservative ideas because they emanated from a party that was 'nasty', selfish, old-fashioned, and incompetent, it could begin to play as well to its traditional strengths on, say, crime (and possibly even immigration and Europe). Cameron, in short, believed in what was coming to be called the 'and theory' of Conservatism, 
namely that, as long as the process were a staged one, it would in the end be perfectly possible for the Party to believe in tight controls on immigration and enlightened attitudes to minorities, to campaign for a greener environment at the same time as reducing the regulatory burden on business, to advocate increased spending on public services at the same time as boosting the role of the voluntary sector in provision. This would become evident when the Party eventually got round to pumping out policy based in part on the recommendation of groups and task forces set up by Cameron on becoming leader. These allowed him to signal straight away that the Party was doing some fresh thinking and that it was seeking to reconnect with professional and other pressure groups it had long ignored. It also allowed him to link the Party with counter-intuitive 'brand signifiers' like Bob Geldof and to tie some older Tory statesmen into the modernisation project at the same time. Most importantly of all perhaps, it helped Cameron hold off the inevitable demand by government spokesmen that he rush into producing policies which Labour could then either steal or rip to shreds.

Cameron anticipated some resistance from within, particularly from the right, but (unlike some of his lieutenants it must be said) preferred to think he could take his party with him without engineering some direct confrontation or a so-called 'Clause IV Moment.' He was helped of course by the fact that, as he had hoped, his potential critics were initially as blown away as everyone else by the frenetic pace that characterised his first hundred days at the helm. But Cameron's task was made much, much easier than that of his predecessors by the extended honeymoon the media afforded a Conservative leader determined to personify, embody and even be the change he was trying to effect - a presidential politician happy to provide them with arresting and intimate visuals and to talk about (and show them) his family life, including, of course, his disabled son. In sharp contrast to his predecessors who were either unwilling or unable to come up with the goods in this respect, here was a politician who was recognisably a human being despite his relatively privileged background. Perhaps the sharpest contrast, however, was provided by the opinion polls which, at best, had barely budged when Hague, Duncan Smith and Howard had taken over. Simply by taking over the leadership just as the Labour government was consumed by internal division and policy arguments, Cameron achieved a stepchange in his Party's rating, taking it into the most sustained lead it had enjoyed since before Black Wednesday in 1992. This ensured that donations came rolling in in much greater amounts and much earlier on in the political cycle than at any time since the 1980s. And, especially as local election results have tended to confirm the opinion polls, it has made it much harder for critics either at Westminster or in the media to moan that whatever he was doing was not only wrong but not working.

Just as crucially, however, Cameron was able to minimise noises off from the right by signalling that, although George Osborne would not be providing them with the upfront tax cuts and spending restraint craved by the economic liberals, he was personally committed to key aspects of the social agenda favoured by the 'High Tories'. Reports produced by a re-animated (and suddenly much more impressive) Iain Duncan Smith on Britain's apparently 'broken society' - reports which focused 
on the need above all to tackle family breakdown - were given a high-profile welcome. And both Cameron and Osborne hinted that they would back their oftprofessed commitment to 'the family' by supporting marriage via the tax and benefits systems - a move that many modernisers were uneasy about and one that it would be difficult to imagine, say, Michael Portillo (often seen as a prototypical Cameroon) making had he made it to the top of the Party in 2001. Cameron also made much, early on, of his belief in 'social responsibility' and of the mantra (another borrowing from the 'faith, flag and family' strain on the right) that 'There is such a thing as society, it's just not the same as the state' - a formula that had the additional benefit of appearing to distance the Party from Margaret Thatcher at the same time as finding favour with those of her disciples who believed government was more often the problem than the solution. The goodwill thus created overrode not only his failure to deliver immediately on his promise to pull Conservative MEPs out of their alliance with the European People's Party (EPP), but also his insistence on respecting the rights of, and according due respect to, women, homosexuals and ethnic minorities. And as long as right-wingers can accept all that in public (even if they privately regard it as politically correct nonsense), Cameron has been happy to bring them onto the frontbench $-\mathrm{a}$ 'big tent' approach that has also helped keep them on board.

Determined that he should lead a party that could retain its principles yet shed any hint of prejudice, one that could appeal to traditionalists and yet pass the 'dinner party test' with the socially-liberal but relatively well-off $\mathrm{AB}$ voters the Tories had to win back to the fold, Cameron made it clear he would stamp down hard and swiftly on anyone who gave even the appearance of racism. Compare the speed with which Homeland Security spokesman, Patrick Mercer, was summarily dismissed with some of the to-ing and fro-ing that went on when similarly offensive remarks were made by Tory MPs under previous leaders. This move (along with Cameron's rapid removal of the whip from Derek Conway, his willingness to demote colleagues like Francis Maude and David Willetts, who have got him into trouble with the party in the country, and his decision to pass responsibility for the Party's media operation from an old chum, George Eustice, to the ex-tabloid editor, Andy Coulson) suggests to many Tories that their leader's judgement and ruthlessness more than makes up for his lack of experience. Likewise, Cameron's impressive performances in the Commons removed from the outset any doubts that he would be able to hold his own against Blair and Brown - a necessary (if not a sufficient) condition of leadership in one of the world's most adversarial systems. Hague and Howard, though not Duncan Smith, were also able to cope in this respect. Where Cameron beats all of them hands-down, however, is in his wider 'message discipline.' Perhaps because he was a PR professional, Cameron knows he (and his lieutenants) have to repeat the same soundbites again and again (and again) over months and even years before they 'cutthrough' to the average voter.

That said, Cameron has proved that he can adjust things when necessary. As it became obvious that Brown was seriously considering a general election in the autumn of 2007, the Tory leader brought forward the rebalancing that his team had always planned, calculating (correctly it turned out) that the public was now ready to 
hear some tougher talk on crime and a signature (but supposedly fully-funded) cut in inheritance tax. Because, however, he knew where he was going, once the emergency had passed, he soon got back onto more 'progressive territory'. Unlike his predecessors, then, Cameron does not so much lurch as calibrate. And, while he has a reverse gear (as he showed when he ran into an unplanned spot of bother over the totemic issue of grammar schools in early 2007), he uses it not to effect a three-point turn, but simply to back up a little in order to drive around the obstacle he is facing something he can do because, unlike his predecessors, he not only knows where he wants to go but has a good idea of how he intends to get there. This also means that he has no need to consult, as they did, the maps foisted on him by the Party's supposed friends in the print media. While he evidently tries very hard to keep them on board - spending time en famille with editors is not uncommon - it is clear that, if necessary, he will stop, let them out and continue on his way without them if he has to. And although Cameron tries to run a relatively collegial Shadow Cabinet, and to ensure that he avoids the charge of inaccessibility levelled at his predecessors, MPs with any ambition to serve in government are also well aware that the same conditions of passage apply to them. 


\section{Not all plain sailing from here on in}

But if Cameron really is 'the full package', he is by no universally acclaimed within his own party. Nor, having caught the wind after October 2007, is he guaranteed a smooth run into Downing Street. Generational replacement, a highly effective Whips' Office, and of course those opinion poll leads and local election results, mean he faces little open criticism. However, there is still some low-level grumbling from the right, especially those whose economic liberalism (and enthusiasm for tax cuts) is not outweighed by their commitment to 'the family' or 'mending the broken society'. The grammar schools row of spring 2007, the flak Cameron attracted after the embarrassing by-election defeat in Ealing Southall, and the criticism he came in for when he visited Rwanda instead of staying in flood-hit Britain, were reminders that he cannot take anything for granted. On the other hand, even his severest critics were impressed with his coolness under fire in the run up to and during the course of the crucial Conservative Party Conference in the autumn of 2007. Inasmuch as reservations are still expressed, they are directed mainly at that Conference's other hero, the Shadow Chancellor George Osborne. Gratitude is a very perishable commodity in politics and, especially after 'yachtgate', there are those, on all sides of the Party, who now wonder whether Cameron's personal loyalty to Osborne (never a particularly popular figure with some older MPs) may mean that the Party is doing less well than it otherwise might be against Darling and Brown.

Such concerns reflect a wider worry about the impact of the economic downturn on the Conservatives' strategy and electoral chances. Cameron's excellent presentation skills made it inevitable he would be accused of being 'all spin and no substance' even before he became leader. And his wealthy background has always led some to wonder whether he could convincingly claim to understand the needs of ordinary people. Given that those selfsame people will be looking for a heavyweight politician to protect and deliver them from a deep recession this may be a big disadvantage. More generally, Cameron's strategy was, at least in part, constructed around a narrative in which the country's economic problems had supposedly been solved in the 1980s and 1990s by a Conservative Party now dedicated instead to sorting out its social malaise and putting it on the path to environmental sustainability. Much of that story no longer seems relevant and Cameron now needs to move fast to come up with a new narrative. So far, he has struggled to do so, and the ongoing search to define a resonant response to the crisis has undermined the message discipline that hitherto was one of his greatest strengths.

The decision from December 2008 onwards to contrast Tory savings and sound finance with Labour's 'debt crisis' has helped in this respect. But it is a risky one. After all, the Party needs the support of millions of people who have less than fond memories of the Conservatives' largely laissez-faire response to the recessions of the early 1980s and 1990s - hence Cameron's concern to prevent his team using rhetoric that reminds voters of the 'if it's not hurting, it's not working' mantras of the Major years. The decision not to rush into reversing Labour's plan to up the top-rate of taxation was probably a wise one. So too was suggesting more help for hard-pressed 
pensioners and those with a little put away in the building society. It is unlikely, however, that politely criticising banks and City traders will change the potentially damaging public perception that the Tories are still, underneath, the political wing of big business rather than a party that looks out for ordinary people. It would be a big gamble for the Conservatives to go into an election giving the impression that they are, as Labour has dubbed them, the 'do-nothing party' - apparently committed, once again, to what Brown and his colleagues will insist on calling cuts. The Tories will of course argue that this is inaccurate: they are, after all, only aiming for a slow-down in the rate of growth. But in the light of his increasingly orthodox calls on the country to live within its means rather than spend its way out of trouble, it could well be the case that the recession has exposed the limits of Cameron's much-trumpeted commitment to the centre ground.

\section{So, has Cameron really got what it takes?}

Given that the Conservative Party has from 1975 onwards chosen its leaders largely because of who they are not, it has, ever since, picked the least well-known candidate of those on offer. Labour did the same in 1983, but not in 1992 or in 1994 when it picked a politician about whom many members had their doubts but who seemed far more likely than his rivals to win it an election. When David Cameron won the leadership contest in 2005, it was by no means certain whether this simply represented a continuation of the Tory trend or a genuine attempt to do what the Party's only serious rival had done. In some ways, because the circumstances are more propitious and because the man they chose has a strategy and a skill-set that is demonstrably superior to those of his predecessors, it no longer really matters. Cameron is not without weaknesses or without critics. Not all of them are things he can do much about but some are sufficiently serious that they might make it more difficult for him than it could or should be to win the next general election. But it is literally impossible to imagine anyone else in the contemporary Conservative Party who would have been able to make as much as he has of the hand he was dealt.

The legendary liberal columnist, and biographer of the last Tory leader to make it from opposition into government, Hugo Young, once had a stab at defining what was required in a political leader:

\footnotetext{
A leader needs nerve: chutzpah in defence of risk is a key component. A leader needs menace: the instilling of a certain fear, growing out of the capacity for dangerous surprise. A leader needs wit: the ability to make swift repartee for television, never flummoxed, sometimes outrageous, usually winning. A leader needs steel: a quiet intransigence of purpose that everybody understands, without always being certain of the inner game he may be playing. ${ }^{12}$
}

Cameron would seem to have all of the first four of what Young termed 'the essential pieces of the leaderly personality'. Whether he has the fifth and final component what Young called 'some kind of vision' - is not yet quite so apparent, and may not become so unless and until he moves into Number Ten. On the other hand, a putative Cameron government will inevitably spend most of its time clearing up the economic mess left by Labour. Likewise, some of the things he has promised to do once in power - particularly with regard to re-jigging this country's relationship with the EU 
and reducing the role of targets in the public sector - could prove very time consuming and even counterproductive. ${ }^{13}$ All of this is likely to leave the man who is likely to be Britain's next Conservative Prime Minister less room than he might like to pursue big ideas, even assuming that, as a self-confessed Tory pragmatist, he really is in the market for them.

Notes 
${ }^{1}$ On Cameron's successful leadership bid, see Andrew Denham and Kieron O'Hara (2008) Democratising Conservative Leadership Selection. From Grey Suits to Grass Roots (Manchester: Manchester University Press), Chapters 5 and 6. See also Timothy Heppell (2007) Choosing the Tory Leader (London: Tauris).

${ }^{2}$ For a more detailed exercise measuring the evidence according to indicators of party change derived from comparative political science, see Tim Bale (2008) "“A Bit Less Bunny-Hugging and a Bit More Bunny-Boiling?" Qualifying Conservative Party Change under David Cameron', British Politics, 3, pp. 270-299. See also Stephen Evans, 'Consigning its Past to History? David Cameron and the Conservative Party', Parliamentary Affairs, 61 (2), pp. 291-314.

${ }^{3}$ Philip Norton 'The Future of Conservatism', Political Quarterly, 79 (3), 2008, pp. 324-332. See also Stuart Ball, 'Factors in Opposition Performance: the Conservative Experience since 1867', in Stuart Ball and Anthony Seldon, Recovering Power: the Conservatives in Opposition (Basingstoke: Palgrave Macmillan, 2005).

${ }^{4}$ Matthew Parris, 'The Force is with David the Unruffled', Times, 10 December 2005

${ }^{5}$ The judgements made here about the balance of power and opinion within the Conservative Party both before and after Cameron became leader are based on documentary and interview research conducted by the author for a forthcoming book on the Party since 1990. The author would like to acknowledge the financial assistance provided by the Leverhulme Trust for that research. For a more concise treatment, see Tim Bale (2009) 'The Conservatives: Trounced, Transfixed, Transformed' in Terrence Casey (ed) The Blair Legacy (Basingstoke: Palgrave).

${ }^{6}$ Figures kindly provided by Philip Cowley. Note though that some of the majority who won their seat in 1997 or after may have sat in the Commons previously.

${ }^{7}$ On the Hague years, see Mark Garnett and Philip Lynch, eds. (2003) The Conservatives in Crisis (Manchester: Manchester University Press).

${ }^{8}$ For how and why it is misguided to label the Conservatives' focus on Europe and immigration a 'core vote' strategy, see Jane Green (2005) 'Conservative party rationality: Learning the lessons from the last election for the next', Journal of Elections, Public Opinion and Parties, 15 (1), pp. 111-127

${ }^{9}$ For a transcript of the speech by Peter Lilley which sent his Party so ballistic - and sent his leader scurrying for cover, see http://www.guardian.co.uk/politics/1999/apr/ 20/conservatives.

${ }^{10}$ Malcolm Gladwell (2008) Outliers: The Story of Success (London: Allen Lane).

${ }^{11}$ David Cameron, 'Modern Conservatism', Demos, 30 January 2006, available online at http://www.demos.co.uk/files/davidcameronmodernconservatism.pdf

${ }^{12}$ Hugo Young, 'Duncan Smith is finished. Voters want a human being', Guardian, 31 October, 2002. 
${ }^{13}$ On the challenges the Conservative Party has, not altogether wisely perhaps, set itself in power, see Tim Bale, 'Passing the Wednesday-Friday Test', Parliamentary Brief, July 152008. 